\title{
Australian Journal of Crop Science \\ Nitrogen use of Panicum and Brachiaria cultivars vary with nitrogen supply: I. Differences in plant growth
}

\author{
Tiago Barreto Garcez, Francisco Antonio Monteiro* \\ Soil Science Department, University of São Paulo (ESALQ) Piracicaba, SP, Brazil
}

\section{*Corresponding author: famontei@usp.br}

\begin{abstract}
Tropical grass pastures are broadly split between those that use high $\mathrm{N}$ fertilizer rates and those that use little or none. Maximizing the efficiency of $\mathrm{N}$ application in pastures requires understanding which features and adaptations species utilize to take advantage. This study was designed to determine the variation in growth of Brachiaria cultivars (Basilisk, Marandu, Piatã and Xaraés) and Panicum cultivars (Aruana, Massai, Mombaça and Tanzania) under two N supply rates (low and high) in order to understanding forage-grass species adaptive mechanisms for high and low $\mathrm{N}$ supply. Changes in growth were determined based on the following characteristics: number of leaves and tillers, leaf area (LA), shoot dry matter (SDM) production, root surface area (RSA), root length (RL) and root dry matter(RDM) production. The experimental design consisted of 8 forage-grass cultivars x $2 \mathrm{~N}$ rates $(30$ and 300 $\mathrm{mg} \mathrm{dm^{-3 }}$ ) in a randomized block design with four replications. At low N supply, Marandu, Xaraés, Piatã, Basilisk and Mombaça cultivars maintained a constant number of tillers but showed a decrease in the number of leaves and LA compared to high $\mathrm{N}$. Tanzania cultivar maintained a constant number of tillers and LA but showed a decrease in the number of leaves under low N. In contrast, cultivars Aruana and Massai showed an increased number of tillers and a reduced LA. At low N rate, Brachiaria cultivars prioritized roots growth but with high $\mathrm{N}$ supply increased leaf and tiller growth. Brachiaria cultivars demonstrated high plasticity of reserve allocation, suggesting that these cultivars may better withstand $\mathrm{N}$ stress, ensuring their persistence. Panicum cultivars exhibited vigorous roots growth which may improve the capture of soil $\mathrm{N}$ and reduce losses from leaching and volatilization, and also can contribute to reduce environment contamination.
\end{abstract}

Keywords: Leaf area; Dry matter partitioning; Root production; Root length; Root surface area

Abbreviations: N_Nitrogen, SDM_Shoot dry-matter, RDM_Root dry-matter, RSA_Root surface area, RL_Root length, LA_Leaf area

\section{Introduction}

Grasses-dominated pastures are used worldwide for livestock production. For example, Brazil has 850 million hectares, of which 102 million hectares are cultivated pastures (IBGE, 2010) that are almost entirely composed of cultivars from the Brachiaria and Panicum genera. These grasses are present in almost all tropical countries including some sub-tropical countries, such as USA (Boddey et al., 2004; Vendramini et al., 2013). Inadequate pasture fertilization and a lack of knowledge regarding the forage crop growth cycle have significantly affected the persistence of pasture production systems and prevent plants from reaching their full productive potential. The forage species choice is the first step to improving these production systems, and the response of different species to nitrogen (N) application is an important selection parameter that requires analysis. The Brachiaria spp. and Panicum spp. cultivars that are used nowadays were first selected in their original habitats, which have distinct soil and climatic conditions and each cultivar was selected according to morphological and productive criteria for livestock grazing. However, the adaptive mechanisms exhibited by these cultivars under stressful conditions have not been adequately studied. Knowledge of plant species' specific adaptive mechanisms is extremely important for maximizing the nutrients efficient use in pasture. This is particularly true for $\mathrm{N}$ (Rao et al., 1995;
Santos et al., 2002; Mommer et al., 2011) because pasture soils exhibit low $\mathrm{N}$ availability and low retention in soil solution. The forage grass productivity is related to continuous leaves and tillers growth, which are responsible for LA renewal and increase in canopy photosynthetic capacity after mechanical harvesting or animals grazing (Lemaire and Chapman, 1996). However, under limited N supply, N-efficient cultivars show tillering, leaf growth behavior, and partitioning of accumulated $\mathrm{N}$ for biomass production characteristics that may contribute to production system longevity (Brégarda et al., 2000; Martuscello et al., 2009; Anwar et al., 2012; Santos et al., 2012). According to Brégarda et al. (2000), biomass partitioning is the key to increase the nitrogen use efficiency (NUE) in grasses. Understanding forage-grass species adaptive mechanisms under $\mathrm{N}$ stress is clearly important for more nutrient efficient utilization of soil and fertilizer $\mathrm{N}$ and for cultivar selection (Yaseen and Malhi, 2009). Thus, this study aimed to analyze morphological changes in shoot and root production in eight forage grasses (Brachiaria brizantha cv. Marandu, B. brizantha cv. Xaraés, B. brizantha cv. Piatã, B. decumbens cv. Basilisk, Panicum maximum cv. Mombaça, $P$. maximum $c v$. Tanzania, $P$. maximum cv. Aruana and $P$. maximum $x P$. infestum cv. Massai) grown in a soil with low and high $\mathrm{N}$ availability. 


\section{Results}

\section{Number of leaves, number of tillers, leaf area and shoot dry} matterproduction

The grasses responses to $\mathrm{N}$ rates in number of leaves, number of tillers and LA for the three harvests varied significantly with cultivars (Table 1). The greatest numbers of leaves were found in Aruana, Massai and Basilisk cultivars at both $\mathrm{N}$ rates. The cultivars' responses (number of leaves) to low $\mathrm{N}$ rate were: $1^{\text {st }}$ Harvest $\left(1^{\text {st }} \mathrm{H}\right)$ Massai $=$ Aruana $=$ Basilisk; $2^{\text {nd }}$ Harvest $\left(2^{\text {nd }} \mathrm{H}\right)$ Massai $=$ Basilisk, Massai $>$ Aruana and Basilisk = Aruana; and $3^{\text {rd }}$ Harvest $\left(3^{\text {rd }} \mathrm{H}\right)$ Aruana $>$ Massai $>$ Basilisk. For the high $\mathrm{N}$ rate, the cultivars responses' were ranked as follows: $1{ }^{\text {st }} \mathrm{H}$ ) Aruana $=$ Basilisk $>$ Massai; $2{ }^{\text {nd }} \mathrm{H}$ ) Massai = Aruana $>$ Basilisk; and $3^{\text {rd }} \mathrm{H}$ ) Aruana = Massai $>$ Basilisk. Piatã and Xaraés tillers consistently produced low number of leaves for both $\mathrm{N}$ rates and three harvest times.

For number of tillers, cultivars responded to low $\mathrm{N}$ rate as follows: $1^{\text {st }} \mathrm{H}$ ) Massai $>$ Aruana $=$ Basilisk $>$ Marandu $=$ Xaraés $=$ Piatã $=$ Mombaça $=$ Tanzania; $2{ }^{\text {nd }} H$ ) responses were similar to the first harvest; and $3^{\text {rd }} \mathrm{H}$ ) Massai = Aruana > Basilisk $=$ Marandu $=$ Xaraés $=$ Mombaça $=$ Tanzania, Basilisk > Piatã. At high $\mathrm{N}$ rate, the following ranking for the number of tillers was observed: $1{ }^{\text {st }} \mathrm{H}$ ) the highest number of tillers occurred on Massai cultivar, and the lowest on Piatã cultivar; $2^{\text {nd }} \mathrm{H}$ ) Massai > Aruana > Basilisk > remaining cultivars; and $3^{\text {rd }} \mathrm{H}$ ) Massai and Aruana the highest number of cultivars, and Piatã had the lowest number of tillers (Table $1)$.

For the first harvest and at low $\mathrm{N}$ rate, LA was similar in Marandu, Xaraés, Mombaça, Tanzania, Aruana and Massai cultivars. In the second harvest, the highest LA values were found in the Marandu, Xaraés, Tanzania and Mombaça cultivars, while the Piatã cultivar had the lowest LA. In the third harvest, the highest LA values were observed in Panicum cultivars, especially Mombaça and Tanzania, and Aruana and Massai cultivars showed LA values equal to Marandu, Xaraés and Basilisk. The high $\mathrm{N}$ rate resulted in the following patterns: $1^{\text {st }} \mathrm{H}$ ) high LA in Xaraés, Basilisk, Mombaça, Tanzania and Aruana cultivars and low LA in Piatã cultivar; $2{ }^{\text {nd }} \mathrm{H}$ ) high LA in the Mombaça cultivar (similar to the other Panicum cultivars, but higher than Brachiaria cultivars) and the lowest LA in Piatã cultivar (Table 1). Response patterns to low $\mathrm{N}$ over successive harvests were identified based on LA, number of leaves and number of tillers: $1^{\text {st }} \mathrm{H}$ ) for the Marandu, Xaraés, Piatã, Basilisk and Mombaça cultivars, the number of tillers remained constant, and the number of leaves decreased prior to a reduction in LA (Fig. 1a, 1b, 1c, 1d and 1e, respectively); $2^{\text {nd }} \mathrm{H}$ ) the Tanzania cultivar showed an increase in the number of tillers and a decrease in the number of leaves, but LA remained constant (Fig. 1f); and $3^{\text {rd }} \mathrm{H}$ ) the Aruana and Massai cultivars showed an increase in the number of tillers and number of leaves, while LA decreased (Fig. $1 \mathrm{~g}$ and $1 \mathrm{~h}$ for Aruana and Massai, respectively). At the high $\mathrm{N}$ rate, almost all cultivars showed similar increase in the number of tillers and LA and a decrease in the number of leaves (unpublished data). The exceptions were Massai and Aruana cultivars, which showed an increase in the number of tillers, number of leaves and LA. The interaction $\mathrm{N}$ rates $\times$ cultivars had was significant for the dry matter production (leaves and stems + sheaths of grasses) of the grasses in the three harvests (Table 2 ). At the high $\mathrm{N}$ rate, leaves and stems + sheaths dry matter increased. The results for leaves dry matter in cultivars growing under low $\mathrm{N}$ rate were: $1^{\text {st }} \mathrm{H}$ ) Mombaça cultivar showed the highest leaves production, while Marandu, Piatã,
Basilisk and Aruana cultivars showed the lowest leaves dry matter production; $2{ }^{\text {nd }} \mathrm{H}$ ) Xaraés, Mombaça, Tanzania and Massai cultivars had the highest leaves dry matter production, while Piatã and Basilisk cultivars had the lowest; $\left.3^{\text {rd }} \mathrm{H}\right)$ Mombaça, Tanzania and Massai cultivars showed the highest whereas Brachiaria cultivars showed the lowest leaves dry matter production. At high $\mathrm{N}$ rate, Mombaça and Piatã cultivars had the highest and lowest production of leaves dry matter, respectively, in the first harvest. In the second harvest, Piatã cultivar showed the lowest leaves dry matter production, while Mombaça, Tanzania and Massai cultivars showed the highest values for leaves dry matter production. In the third harvest, the Piatã cultivar showed a response similar to the first two harvests, and the Panicum cultivars showed highest leaves dry matter production.

Stems + sheaths dry matter showed similar results among the cultivars (Table 2). The results for stems + sheaths dry matter in cultivars growing at the low $\mathrm{N}$ rate were: $1{ }^{\mathrm{st}} \mathrm{H}$ ) Basilisk cultivar showed the highest stems + sheaths dry matter production, and Massai cultivar showed lowest stems + sheaths dry matter production; $2^{\text {nd }} \mathrm{H}$ ) Massai cultivar showed the lowest stems + sheaths dry matter production, while Marandu cultivar was among the cultivars that produced relatively high levels of stems + sheaths dry matter, $3^{\text {rd }} \mathrm{H}$ ) Basilisk, Mombaça and Aruana showed high values for stems + sheaths dry matter, while Piatã and Massai had low stems + sheaths dry matter values. Under high $\mathrm{N}$ rate, Piatã cultivar showed the lowest stems + sheaths dry matter production, while Basilisk was among the greatest producers of stems + sheaths dry matter over the three harvests.

The interaction $\mathrm{N}$ rates $\times$ cultivars was significant for shoot dry matter production in all three harvests (Fig. 2). Low N availability in the soil during forage grasses establishment phase (Fig. 2a) resulted in greater shoot dry matter for Mombaça cultivar than the other cultivars, while Marandu, Piatã and Aruana cultivars showed the lowest SHOOT DRY MATTERproduction. In the second harvest, Piatã, Basilisk and Massai cultivars showed the lowest shoot dry matter production (Fig. 2b). In the third harvest, Mombaça cultivar produced more shoot dry matter than the other cultivars (except for Tanzania) and Piatã cultivar showed the lowest SHOOT DRY MATTERproduction (Fig. 2c). High N availability in the soil resulted in the following ranking of SHOOT DRY MATTERproduction: $1{ }^{\text {st }} \mathrm{H}$ ) Mombaça = Tanzania, Mombaça $>$ other cultivars, Tanzania $=$ Basilisk $>$ Marandu $=$ Xaraés $=$ Aruana $=$ Massai $>$ Piatã; $2^{\text {nd }} \mathrm{H}$ ) Panicum cultivars exhibited high SHOOT DRY MATTERproduction, and Mombaça cultivar produced more dry matter than all Brachiaria cultivars, but Xaraés and Basilisk cultivars produced dry matter similar to some of the Panicum cultivars; $3^{\text {rd }} \mathrm{H}$ ) Panicum spp. > the remaining grasses, Xaraés $=$ Basilisk, Basilisk $=$ Marandu, and Xaraés $>$ Marandu > Piatã.

\section{Surface area, length and dry matter production of roots}

The interaction of $\mathrm{N}$ rates $\times$ cultivars was significant for the dry matter production, surface area and length of roots (Fig. 3). The high $\mathrm{N}$ rate increased ROOT DRY MATTER production in Mombaça and Tanzania cultivars, with the lowest production observed in Piatã cultivar. However, the production of Piatã cultivar was not different than Marandu and Xaraés cultivars. At the low $\mathrm{N}$ rate, the following ranking of dry matter production was observed: Mombaça = Tanzania $>$ other cultivars, except Aruana; Aruana = Massai, and Panicum spp. $>$ Marandu $=$ Xaraés $=$ Piatã $=$ Basilisk $($ Fig. 3a). 
Table 1. Number of leaves, number of tillers and leaf area at the first, second and third harvests of Brachiaria cultivars and Panicum cultivars grown at low and high nitrogen rates.

\begin{tabular}{|c|c|c|c|c|c|c|c|c|c|c|c|c|}
\hline \multirow{4}{*}{$\begin{array}{l}\text { Cultivars } \\
1^{\text {st }} \text { harvest } \\
\text { Marandu }\end{array}$} & \multicolumn{4}{|c|}{ Number of leaves } & \multicolumn{4}{|c|}{ Number of tillers } & \multicolumn{4}{|c|}{ Leaf area } \\
\hline & \multicolumn{2}{|c|}{ Low N } & \multicolumn{2}{|c|}{ High N } & \multirow{2}{*}{\multicolumn{2}{|c|}{$\begin{array}{l}\text { Low N } \\
\text { Tillers/pot }\end{array}$}} & \multirow{2}{*}{\multicolumn{2}{|c|}{ High N }} & \multirow{2}{*}{$\frac{\text { Low N }}{\mathrm{cm}^{2} / \text { pot }}$} & \multicolumn{3}{|c|}{ High $\mathrm{N}$} \\
\hline & \multicolumn{4}{|c|}{ Leaves/pot } & & & & & & & & \\
\hline & 92 & bcd & 108 & $\mathrm{~cd}$ & 23 & $\mathrm{c}$ & 34 & $\mathrm{c}$ & 1877 & $a b c$ & 2909 & b \\
\hline Xaraés & 76 & $\mathrm{~cd}$ & 92 & de & 21 & $\mathrm{c}$ & 30 & $\mathrm{c}$ & 2121 & $a b$ & 3664 & $a b$ \\
\hline Piatã & 73 & d & 67 & $\mathrm{e}$ & 18 & $\mathrm{c}$ & 16 & $\mathrm{~d}$ & 1330 & $\mathrm{c}$ & 1228 & $\mathrm{c}$ \\
\hline Basilisk & 123 & $\mathrm{a}$ & 190 & $\mathrm{a}$ & 36 & $\mathrm{~b}$ & 60 & $\mathrm{~b}$ & 1681 & $\mathrm{bc}$ & 4129 & $a b$ \\
\hline Mombaça & 93 & $\mathrm{bc}$ & 118 & $\mathrm{~cd}$ & 22 & $\mathrm{c}$ & 25 & $\mathrm{~cd}$ & 2498 & $\mathrm{a}$ & 4548 & $\mathrm{a}$ \\
\hline Tanzânia & 101 & $\mathrm{~b}$ & 148 & $\mathrm{~b}$ & 20 & $\mathrm{c}$ & 31 & $\mathrm{c}$ & 2061 & $a b$ & 4406 & $a b$ \\
\hline Aruana & 127 & $\mathrm{a}$ & 201 & $\mathrm{a}$ & 40 & $\mathrm{~b}$ & 66 & $\mathrm{~b}$ & 2080 & $a b$ & 3507 & $a b$ \\
\hline Massai & 137 & $\mathrm{a}$ & 161 & $\mathrm{~b}$ & 63 & $\mathrm{a}$ & 79 & $\mathrm{a}$ & 1958 & $a b c$ & 2939 & $\mathrm{~b}$ \\
\hline Mean & 103 & & 136 & & 30 & & 43 & & 1951 & & 3416 & \\
\hline \multicolumn{13}{|l|}{ F test } \\
\hline $\mathrm{N}$ & \multicolumn{4}{|c|}{$* *$} & \multicolumn{4}{|c|}{$* *$} & \multicolumn{4}{|c|}{ ** } \\
\hline Cultivar & \multicolumn{4}{|c|}{$* *$} & \multicolumn{4}{|c|}{$* *$} & \multicolumn{4}{|c|}{$* *$} \\
\hline N x Cultivar & & & $* *$ & & & & $* *$ & & & & ** & \\
\hline $\mathrm{CV}(\%)$ & & & 8.6 & & & & 11.3 & & & & 16.8 & \\
\hline $2^{\text {nd }}$ harvest & & Lea & & & & & rs/pot & & & & & \\
\hline Marandu & 38 & c & 85 & c & 25 & $\mathrm{c}$ & 41 & d & 1790 & abc & 5448 & b \\
\hline Xaraés & 23 & $\mathrm{c}$ & 62 & $\mathrm{c}$ & 23 & $\mathrm{c}$ & 49 & $\mathrm{~d}$ & 1898 & $a b$ & 5577 & $\mathrm{~b}$ \\
\hline Piatã & 38 & $\mathrm{c}$ & 52 & $\mathrm{c}$ & 22 & $\mathrm{c}$ & 25 & $\mathrm{~d}$ & 1052 & $\mathrm{~d}$ & 1292 & $\mathrm{c}$ \\
\hline Basilisk & 80 & $a b$ & 173 & $\mathrm{~b}$ & 43 & $\mathrm{~b}$ & 76 & $\mathrm{c}$ & 1477 & $\mathrm{c}$ & 5221 & $\mathrm{~b}$ \\
\hline Mombaça & 31 & $\mathrm{c}$ & 90 & $\mathrm{c}$ & 24 & $\mathrm{c}$ & 46 & $\mathrm{~d}$ & 1954 & $a b$ & 7783 & $\mathrm{a}$ \\
\hline Tanzânia & 39 & $\mathrm{c}$ & 91 & $\mathrm{c}$ & 25 & $\mathrm{c}$ & 41 & $\mathrm{~d}$ & 2107 & $\mathrm{a}$ & 6399 & $a b$ \\
\hline Aruana & 63 & $\mathrm{~b}$ & 220 & $\mathrm{a}$ & 44 & $\mathrm{~b}$ & 109 & $\mathrm{~b}$ & 1593 & $\mathrm{bc}$ & 6598 & $a b$ \\
\hline Massai & 85 & $\mathrm{a}$ & 226 & $\mathrm{a}$ & 81 & $\mathrm{a}$ & 149 & $\mathrm{a}$ & 1543 & $\mathrm{bc}$ & 6330 & $a b$ \\
\hline Mean & 50 & & 125 & & 36 & & 67 & & 1677 & & 5581 & \\
\hline F test & & & & & & & & & & & & \\
\hline $\mathrm{N}$ & & & $* *$ & & & & $* *$ & & & & $* *$ & \\
\hline Cultivar & & & $* *$ & & & & $* *$ & & & & $* *$ & \\
\hline N x Cultivar & & & $* *$ & & & & $* *$ & & & & $* *$ & \\
\hline CV (\%) & & & 13.6 & & & & 15.3 & & & & 13.5 & \\
\hline $3^{\text {rd }}$ harvest & & Lea & & & & & rs/pot & & & & & \\
\hline Marandu & 53 & $\mathrm{c}$ & 107 & $\mathrm{c}$ & 27 & $\mathrm{bc}$ & 53 & $\mathrm{bc}$ & 895 & $\mathrm{bc}$ & 3616 & $\mathrm{~b}$ \\
\hline Xaraés & 17 & $\mathrm{e}$ & 90 & $\mathrm{c}$ & 19 & $\mathrm{bc}$ & 59 & $\mathrm{bc}$ & 742 & $\mathrm{bc}$ & 4844 & $a b$ \\
\hline Piatã & 23 & $\mathrm{e}$ & 31 & $\mathrm{~d}$ & 13 & $\mathrm{c}$ & 6 & $\mathrm{~d}$ & 315 & $\mathrm{c}$ & 317 & $\mathrm{c}$ \\
\hline Basilisk & 62 & $\mathrm{c}$ & 206 & $\mathrm{~b}$ & 35 & $\mathrm{~b}$ & 78 & $\mathrm{~b}$ & 798 & $\mathrm{bc}$ & 3977 & $\mathrm{~b}$ \\
\hline Mombaça & 33 & de & 97 & $\mathrm{c}$ & 24 & $\mathrm{bc}$ & 42 & $\mathrm{c}$ & 1554 & $\mathrm{a}$ & 5556 & $a b$ \\
\hline Tanzânia & 47 & $\mathrm{~cd}$ & 118 & $\mathrm{c}$ & 30 & $\mathrm{bc}$ & 57 & $\mathrm{bc}$ & 1599 & $\mathrm{a}$ & 6736 & $\mathrm{a}$ \\
\hline Aruana & 117 & $\mathrm{a}$ & 284 & $\mathrm{a}$ & 70 & $\mathrm{a}$ & 144 & $\mathrm{a}$ & 1041 & $\mathrm{ab}$ & 6677 & $\mathrm{a}$ \\
\hline Massai & 91 & $\mathrm{~b}$ & 257 & $\mathrm{a}$ & 72 & $\mathrm{a}$ & 165 & $\mathrm{a}$ & 1263 & $a b$ & 6201 & $\mathrm{a}$ \\
\hline Mean & 55 & & 149 & & 36 & & 75 & & 1026 & & 4740 & \\
\hline$F$ test & & & & & & & & & & & & \\
\hline $\mathrm{N}$ & & & $* *$ & & & & $* *$ & & & & $* *$ & \\
\hline Cultivar & & & $* *$ & & & & $* *$ & & & & ** & \\
\hline N x Cultivar & & & $* *$ & & & & $* *$ & & & & $* *$ & \\
\hline $\mathrm{CV}(\%)$ & & & 16.1 & & & & 25.7 & & & & 30.6 & \\
\hline
\end{tabular}

Means followed by the same letter in each sub-column for each plant harvest are not significant at the $5 \%$ probability rate according to Tukey’s test. **Significant at $1 \%$ probability.

The cultivars ROOT SURFACE AREA (RSA)responses at low $\mathrm{N}$ rate were: Mombaça cultivar exhibited a greater ROOT SURFACE AREA (RSA)than the other cultivars, except for Tanzania and Aruana; Piatã cultivar had the smallest RSA, but its ROOT SURFACE AREA (RSA)did not differ from the other Brachiaria cultivars. The cultivar responses to high $\mathrm{N}$ rate were similar to those at the low $\mathrm{N}$ rate (Fig. 3b). The low $\mathrm{N}$ rate resulted in greater $\mathrm{RL}$ in Aruana and Mombaça cultivars. Tanzania cultivar RL did not differ from Mombaça cultivar. Piatã cultivar had the shortest roots, but the ROOT LENGTH (RL) value for this cultivar was not significantly different from Marandu and Xaraés cultivars. At the high $\mathrm{N}$ rate, Panicum cultivars exhibited the longest roots. However, Marandu, Xaraés and Basilisk cultivars had root length that was not different from Massai cultivar. Piatã cultivar had the shortest roots, but its ROOT LENGTH (RL) value was similar to Marandu, Xaraés and Basilisk cultivars (Fig. 3c)

\section{Proportion of dry matterproduction}

Shoot dry matter in the third harvest was used to calculate grasses dry matter allocation among roots, sheaths+ stems and leaves. At the low $\mathrm{N}$ rate, Marandu, Xaraés and Piatã 

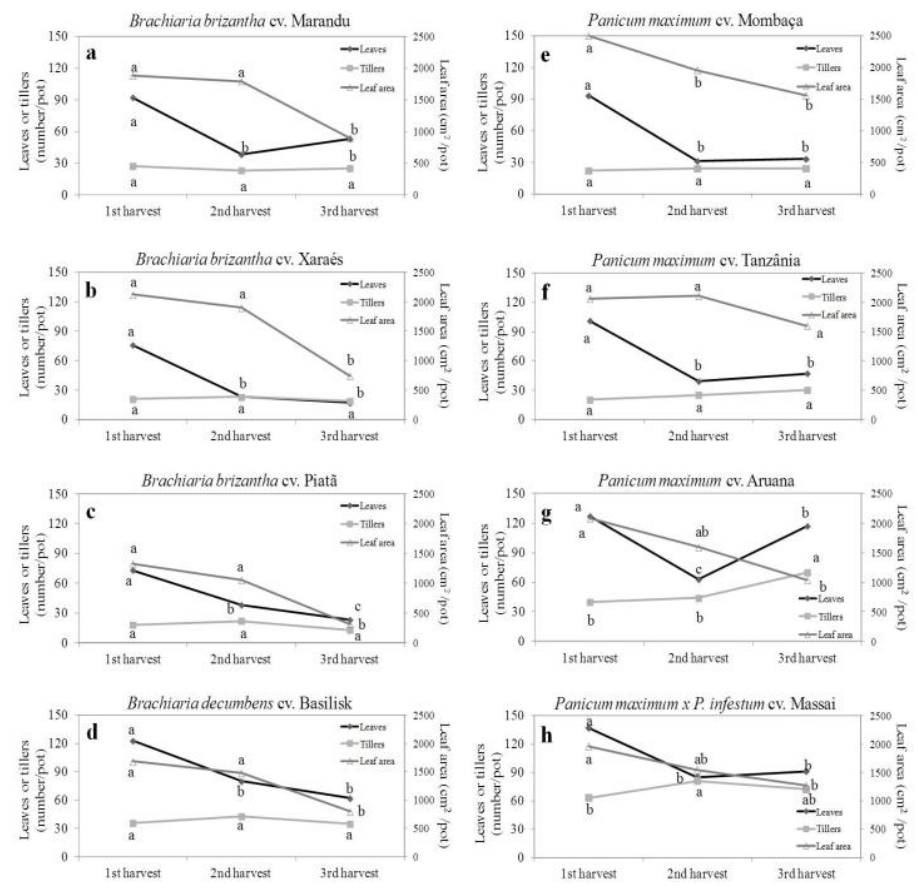

Fig 1. Response patterns at three harvests of Brachiaria and Panicum cultivars grown at low rates of nitrogen (means followed by the same letter within each cultivar and response variable are not significant at the $5 \%$ probability rate).

cultivars showed similar leaves, stems + sheaths and roots dry matter proportions (Fig. 4). In particular, Basilisk cultivar had the greatest roots proportion. Leaf dry matter proportion was higher in $B$. brizantha cultivars than $B$. decumbens cultivar. Among Panicum cultivars, the proportion of roots was relatively high in Aruana, while the proportion of leaves was relatively high in Massai. Compared to low $\mathrm{N}$ rate, high $\mathrm{N}$ rate resulted in a greater contribution of leaves and stems + sheaths to the total dry matter in Marandu, Xaraés and Piatã cultivars. Aboveground dry matter as a proportion of total dry matter was higher for the Basilisk cultivar than in other cultivars, especially with regard to stems + sheaths (Fig. 4). At high $\mathrm{N}$ rate, it was found high proportion of leaves and stems + sheaths in the Mombaça and Tanzania cultivars. In Massai and Aruana cultivars, high $\mathrm{N}$ rate resulted in a low proportion of roots and high proportion of leaves and stems + sheaths (Fig. 4).

\section{Discussion}

An increase in $\mathrm{N}$ rate resulted in an increase in the number of leaves in all cultivars (Table 1) due to $\mathrm{N}$ stimulation of new leaf formation (Oliveira et al., 2007). However, increases in grasses dry matter production depend not only on the number of leaves but also on leaf shape, size and arrangement (Parsons et al., 1983; Giacomini et al., 2009; Vilela et al., 2012). Therefore, the number of leaves alone cannot be used to evaluate forage grass production potential. In this study, the overall dry matter production of Basilisk, Aruana and Massai cultivars did not increase as the $\mathrm{N}$ rate was increased (Fig. 2). In addition to the number of leaves, LA must also be considered. An addition in N supply usually enhances plant's photosynthetic efficiency (Parsons et al., 1983) by increasing leaf elongation and expansion, thereby resulting in high light absorption area (Chapman and Lemaire, 1993; Akmal and Janssens, 2004). With more leaf area for light absorption, the photosynthetic rate is increased, with consequent increases in biomass production (Pilbeam, 2011). Mombaça cultivar had low number of leaves under both $\mathrm{N}$ rates but had a greater LA than the other cultivars, which resulted in high leaf dry matter production (Table 2). The response of Xaraés cultivar was also similar to Mombaça cultivar. Xaraés cultivar produced few leaves but showed a high LA (Table 2). The grasses' growth pattern can interfere in the use of applied $\mathrm{N}$ in terms of SDM production (Ryser and Lambers, 1995; Anwar et al., 2012). Massai, Aruana and Basilisk cultivars displayed a high number of leaves and tillers under both $\mathrm{N}$ rates (Table 1). These plants used energy to grow tillers and leaves and this resulted in a relatively low leaves and stems + sheaths dry matter (Tables 1 and 2) and lower total dry matter than in Mombaça cultivar (Fig. 2). There is a negative correlation between the number and mass of tillers within a cultivar, which prevents late buds from producing new tillers (Matthew et al., 1995; Nabinger and Medeiros, 1992; Santos et al., 2009; Santos et al., 2011). For this reason, high tiller production results in a lower dry matter of the tillers and, consequently, of shoots (Fig. 2), as was observed in Massai and Aruana cultivars. At low $\mathrm{N}$ rate, Basilisk cultivar behaved differently from Massai and Aruana cultivars, showing increased stems + sheaths dry matter with an increased numbers of leaves. This cultivar also had one of the smallest leaf-area values. The response of Basilisk cultivar to low $\mathrm{N}$ availability may have been due to decumbent growth (the stimulation of new leaves and tillers) to decrease water loss and provide protection against attack by herbivores in their natural habitat. This type of growth is an adaptive mechanism for survival in a stressful environment. The availability of $\mathrm{N}$ controls the process of plant development by rapidly initiating axillary bud formation and the corresponding tillers (Nabinger and Medeiros, 1992). However, each cultivar exhibit adaptations that are specific to the environment in which it was selected, specifically in terms of $\mathrm{N}$ utilization and the partitioning of assimilated carbon for dry matter production (Anwar et al., 2012). According to Nabinger and Pontes (2001), when photosynthesis is limited (e.g., due to a lack of N), there is an initial reduction in tiller formation, followed by increased life span of the leaves and, finally, a reduction in leaves size. However, in the last two harvests, as nutrient stress increased under low N rate, Marandu, Xaraés, Piatã, Basilisk and Mombaça cultivars initially maintained their number of tillers, while the number of leaves was reduced prior to a reduction in LA (Fig. 1a, 1b, 1c, 1d and 1e). In Tanzania cultivar, LA and tillers remained constant (Fig. 1f) and the number of leaves decreased. In contrast, Aruana and Massai cultivars showed an increased number of tillers and leaves, but with a lower LA compared to previous harvests (Fig. 1g and $1 \mathrm{~h}$ ). Another strategy of grasses adapted to low-fertility soils for soil nutrient utilization involves allocation of a large proportion of photosynthetically fixed carbon to root production (Rao et al. 1995) when plants are under stressed conditions. The rapid initial growth of the root system is believed to be the main factor increasing $\mathrm{N}$ absorbed by these plants (Liao et al., 2004; Noulas et al., 2010), and this behavior favors grasses persistence in production system. Mombaça and Tanzania produced the highest root dry matter under both $\mathrm{N}$ rates (Fig. 3c), indicating that these cultivars with lush root growth also show high dry matter shoots production (Fig. 2). Burton (1943) reported that subtropical grasses differ in root growth and that Paspalum notatum (bahiagrass) shows high root growth in number and length, which may be due to better $\mathrm{N}$ use (Acuña et al., 2010). Santos et al. (2002) found that Poa trivialis, when removed 
Table 2. Production of leaf dry matter (LDM) and stems + sheaths dry matter (SSDM) at the first, second and third harvests of Brachiaria and Panicum cultivars grown at low and high nitrogen rates.

\begin{tabular}{|c|c|c|c|c|c|c|c|c|}
\hline \multirow[b]{2}{*}{ Cultivars } & \multicolumn{4}{|c|}{ LDM } & \multicolumn{4}{|c|}{ SSDM } \\
\hline & Low $\mathrm{N}$ & \multicolumn{3}{|c|}{ High N } & Low $\mathrm{N}$ & \multicolumn{3}{|c|}{ High N } \\
\hline $1^{\text {st }}$ harvest & g/pot & & & & g/pot & & & \\
\hline Marandu & 10.9 & de & 14.0 & $\mathrm{~d}$ & 4.3 & $\mathrm{de}$ & 5.1 & $\mathrm{~cd}$ \\
\hline Xaraés & 14.0 & $\mathrm{bc}$ & 19.0 & $\mathrm{c}$ & 6.1 & bcd & 6.9 & $\mathrm{c}$ \\
\hline Piatã & 9.9 & de & 7.6 & $\mathrm{e}$ & 4.5 & de & 2.7 & $\mathrm{~d}$ \\
\hline Basilisk & 9.5 & $\mathrm{e}$ & 17.8 & $\mathrm{~cd}$ & 9.8 & $\mathrm{a}$ & 17.5 & $\mathrm{a}$ \\
\hline Mombaça & 17.8 & $\mathrm{a}$ & 32.2 & $\mathrm{a}$ & 7.7 & bcd & 12.3 & $\mathrm{~b}$ \\
\hline Tanzânia & 14.6 & $\mathrm{~b}$ & 26.3 & $\mathrm{~b}$ & 6.6 & bcd & 10.7 & $\mathrm{~b}$ \\
\hline Aruana & 8.8 & $\mathrm{e}$ & 16.3 & $\mathrm{~cd}$ & 5.5 & cde & 10.3 & $\mathrm{~b}$ \\
\hline Massai & 12.0 & $\mathrm{~cd}$ & 16.5 & $\mathrm{~cd}$ & 3.8 & $\mathrm{e}$ & 5.6 & $\mathrm{~cd}$ \\
\hline Mean & 12.2 & & 18.7 & & 6.0 & & 8.9 & \\
\hline \multicolumn{9}{|l|}{ F test } \\
\hline $\mathrm{N}$ & & & $* *$ & & & & $* *$ & \\
\hline Cultivar & & & $* *$ & & & & $* *$ & \\
\hline $\mathrm{N} x$ Cultivar & & & $* *$ & & & & $* *$ & \\
\hline $\mathrm{CV}(\%)$ & & & 11.0 & & & & 14.3 & \\
\hline $2^{\text {nd }}$ harvest & \multicolumn{4}{|c|}{$\mathrm{g} / \mathrm{pot}$} & \multicolumn{4}{|c|}{ g/pot } \\
\hline Marandu & 8.6 & b & 17.9 & c & 5.8 & $\mathrm{a}$ & 9.4 & $\mathrm{~d}$ \\
\hline Xaraés & 9.5 & $a b$ & 26.3 & $\mathrm{~b}$ & 5.2 & $a b$ & 14.3 & $a b c$ \\
\hline Piatã & 5.3 & $\mathrm{c}$ & 6.5 & $\mathrm{~d}$ & 4.3 & $\mathrm{~b}$ & 4.5 & $\mathrm{e}$ \\
\hline Basilisk & 5.7 & $\mathrm{c}$ & 17.9 & $\mathrm{c}$ & 5.2 & $a b$ & 17.5 & $a b$ \\
\hline Mombaça & 10.6 & $\mathrm{a}$ & 35.9 & $\mathrm{a}$ & 4.2 & $\mathrm{~b}$ & 14.7 & $a b$ \\
\hline Tanzânia & 10.3 & $\mathrm{a}$ & 31.3 & $\mathrm{a}$ & 4.4 & $\mathrm{~b}$ & 13.6 & bcd \\
\hline Aruana & 8.1 & $\mathrm{~b}$ & 25.8 & $\mathrm{~b}$ & 4.6 & $\mathrm{~b}$ & 19.0 & $\mathrm{a}$ \\
\hline Massai & 9.5 & $a b$ & 31.4 & $\mathrm{a}$ & 1.9 & $\mathrm{c}$ & 9.9 & $\mathrm{~cd}$ \\
\hline Mean & 8.5 & & 24.1 & & 4.5 & & 12.9 & \\
\hline \multicolumn{9}{|l|}{ F test } \\
\hline $\mathrm{N}$ & & & $* *$ & & & & $* *$ & \\
\hline Cultivar & & & $* *$ & & & & $* *$ & \\
\hline $\mathrm{N} x$ Cultivar & & & $* *$ & & & & $* *$ & \\
\hline $\mathrm{CV}(\%)$ & & & 9.0 & & & & 12.0 & \\
\hline $3^{\text {rd }}$ harvest & \multicolumn{4}{|c|}{$\mathrm{g} / \mathrm{pot}$} & \multicolumn{4}{|c|}{$\mathrm{g} / \mathrm{pot}$} \\
\hline Marandu & 5.0 & $\mathrm{c}$ & 14.6 & $\mathrm{~d}$ & 1.9 & $\mathrm{bc}$ & 6.3 & $\mathrm{c}$ \\
\hline Xaraés & 4.7 & $\mathrm{~cd}$ & 22.6 & $\mathrm{bc}$ & 2.0 & $\mathrm{bc}$ & 10.3 & $\mathrm{bc}$ \\
\hline Piatã & 2.1 & $\mathrm{~d}$ & 2.8 & $\mathrm{e}$ & 1.1 & $\mathrm{c}$ & 1.1 & $\mathrm{~d}$ \\
\hline Basilisk & 3.5 & $\mathrm{~cd}$ & 16.1 & $\mathrm{~cd}$ & 2.3 & $a b c$ & 13.4 & $\mathrm{ab}$ \\
\hline Mombaça & 9.8 & a & 32.7 & $\mathrm{a}$ & 3.5 & $\mathrm{a}$ & 13.5 & $\mathrm{ab}$ \\
\hline Tanzânia & 8.5 & $a b$ & 34.2 & $\mathrm{a}$ & 3.2 & $a b$ & 16.4 & $\mathrm{a}$ \\
\hline Aruana & 6.0 & $\mathrm{bc}$ & 27.8 & $a b$ & 2.2 & $\mathrm{bc}$ & 15.4 & $\mathrm{a}$ \\
\hline Massai & 8.1 & $a b$ & 33.7 & $\mathrm{a}$ & 1.3 & $\mathrm{c}$ & 17.4 & $\mathrm{a}$ \\
\hline Mean & 6.0 & & 23.0 & & 2.2 & & 11.7 & \\
\hline \multicolumn{9}{|l|}{ F test } \\
\hline $\mathrm{N}$ & & & $* *$ & & & & $* *$ & \\
\hline Cultivar & & & $* *$ & & & & $* *$ & \\
\hline $\mathrm{N} x$ Cultivar & & & $* *$ & & & & $* *$ & \\
\hline $\mathrm{CV}(\%)$ & & & 14.0 & & & & 21.0 & \\
\hline
\end{tabular}

Means followed by the same letter in each sub-column for each plant harvest are not significant at the $5 \%$ probability according to Tukey's test. ** Significant at the $1 \%$ probability rate.

from an environment with suitable $\mathrm{N}$ concentrations to another environment without available $\mathrm{N}$, could immediately interrupt $\mathrm{N}$ allocation for tiller growth. In contrast, Panicum maximum cv. Tanzania continued to allocate $\mathrm{N}$ primarily towards the growth of new leaves and tillers, but over time, the roots required the largest amount of N. Santos et al. (2012) confirmed that the majority of $\mathrm{N}$ in the Tanzania cultivar is used for the growth of new leaves and lateral tillers. Martuscello et al. (2009) concluded that for Brachiaria brizantha cv. Xaraés and $P$. maximum $\mathrm{x} P$. infestum $\mathrm{cv}$. Massai, $\mathrm{N}$ was primarily allocated to the growth of the shoots and not the roots. Acuna et al. (2010) observed that absorbed $\mathrm{N}$ was preferentially assimilated in the shoots of Paspalum notatum (bahiagrass). In this study, low $\mathrm{N}$ supply resulted in a greater proportion of root dry matter in the total dry matter of Marandu, Xaraés, Piatã and Basilisk cultivars compared to the proportions of total dry matter under a high $\mathrm{N}$ supply. Among these cultivars, Basilisk showed the lowest proportion of root dry matter (Fig. 4). Rao et al. (1995) evaluated seven tropical forage grasses and observed that cultivars that were markedly adapted to soils with low fertility showed increasing proportions of biomass 

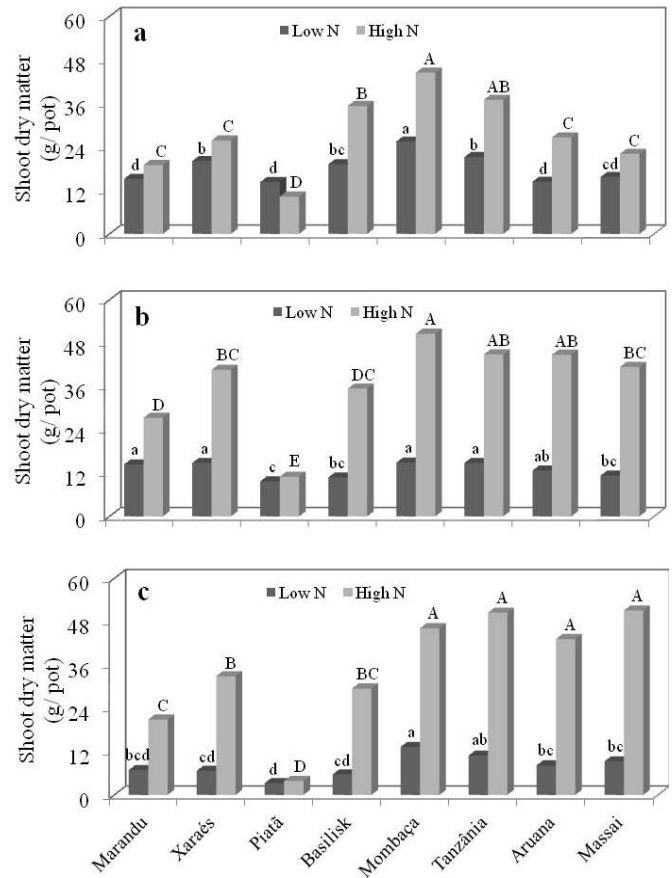

Fig 2. Shoot dry matterproduction at the first (a), second (b) and third (c) harvests of Brachiaria spp. and Panicum spp. grown at low and high nitrogen rates (means followed by the same lowercase letter for the low nitrogen rate and the same uppercase letter for the high nitrogen rate were not significant at the $5 \%$ probability rate).
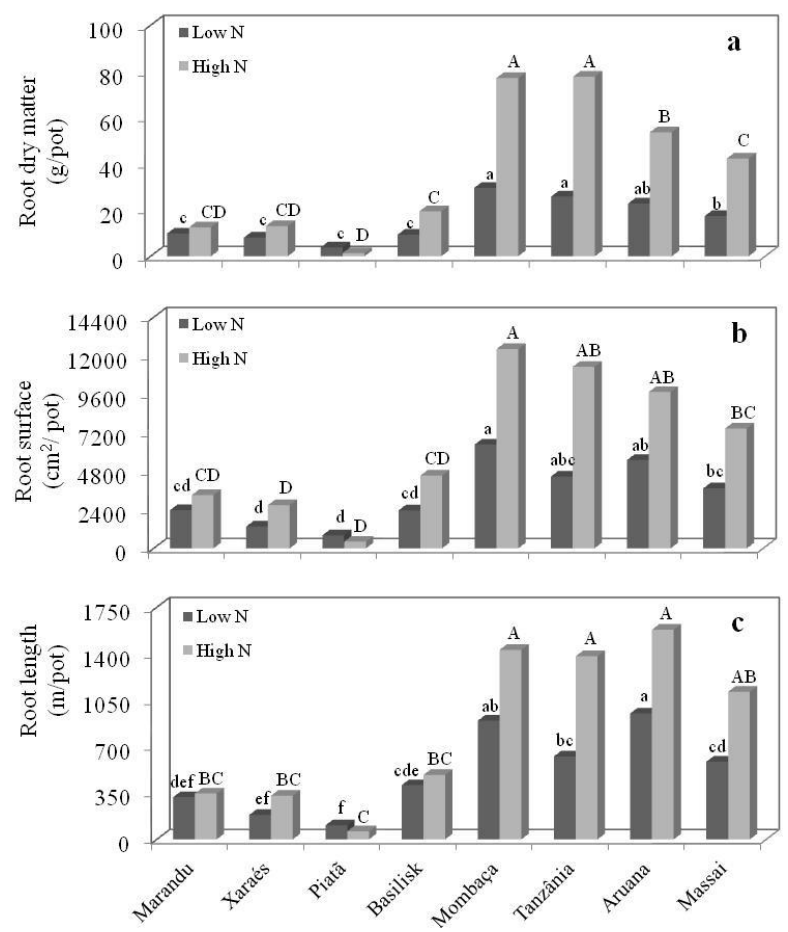

Fig 3. Root dry matterproduction (A), surface (B) and length (L) of Brachiaria spp. and Panicum spp. at low and high nitrogen rates (means followed by the same lowercase letter for the low nitrogen rates and uppercase letters for the high nitrogen rates were not significant at the $5 \%$ probability rate). allocated to root growth at the expense of shoot growth. Under high $\mathrm{N}$ rate, Mombaça and Tanzania cultivars showed an increased proportion of leaves and stems + sheaths, although the proportion of root dry matter remained high, which is similar to that was observed under the low $\mathrm{N}$ rate. Massai and Aruana cultivars showed decreased proportions of root dry matter and increased proportions of leaves and stems + sheaths dry matter under high $\mathrm{N}$ supply, showing the greater plasticity of these cultivars compared to the other two Panicum cultivars.

\section{Materials and Methods}

\section{Plant materials and greenhouse conditions}

The experiment was carried out during the summer season in a greenhouse located in Piracicaba, São Paulo State, Brazil, using the forage grasses Brachiaria brizantha cv. Marandu, $B$. brizantha cv. Xaraés, B. brizantha cv. Piatã, B. decumbens cv. Basilisk, Panicum maximum cv. Mombaça, P. maximum cv. Tanzania, $P$. maximum cv. Aruana and $P$. maximum $x P$. infestum cv. Massai. Grass seeds were germinated in plastic trays containing washed sand and supplied with adequate moisture for germination. The seedlings were transplanted 12 days after sowing, after they had two to three leaves. Fifteen seedlings were transplanted into each pot and successively thinned to five plants per pot.

The grasses were grown in $4.2 \mathrm{dm}^{3}$ plastic pots containing $6 \mathrm{~kg}$ soil over three growing seasons. Plant harvesting was performed at $5 \mathrm{~cm}$ above the soil surface. Each harvest was made when the more mature leaves had begun to senesce, and the first, second and third harvests occurred at 26, 50 and 72 days of growth, respectively. The mean temperature and humidity of the air inside the greenhouse during the experimental period was $29.6{ }^{\circ} \mathrm{C}\left(\mathrm{Tmax}=44.1{ }^{\circ} \mathrm{C} / \mathrm{Tmin}=\right.$ $19.5{ }^{\circ} \mathrm{C}$ ) and $63.4 \%$, respectively. The four Brachiaria cultivars and four Panicum cultivars were supplied with high $\left(300 \mathrm{mg} \mathrm{dm}^{-3}\right.$ of soil) and low (30 mg dm${ }^{-3}$ of soil) $\mathrm{N}$ rates in an $8 \times 2$ factorial design, similar to previous experiments carried out by Batista and Monteiro (2008) and De Bona and Monteiro (2010). The experiment was set in a completely randomized block design with four replications, and ammonium nitrate was used as the $\mathrm{N}$ source. To avoid other potential limitations to growth, $\mathrm{P}, \mathrm{K}, \mathrm{Ca}, \mathrm{Mg}, \mathrm{S}, \mathrm{B}, \mathrm{Cu}, \mathrm{Zn}$ and Mo were applied to the soil in amounts of 150,150, 60, $50,30,1.5,2.5,2.0$ and $0.25 \mathrm{mg} \mathrm{dm}^{-3}$ of soil, respectively, in the beginning of the experiment and after each harvest. To prevent abrupt variations in soil salinity, $\mathrm{N}$ and $\mathrm{K}$ applications were applied as three separate events, with three days between each application. For the second and third harvests, the $\mathrm{P}$ application was reduced to $75 \mathrm{mg} \mathrm{dm}^{-3}$ of soil.

\section{Soil characterization}

The soil used in the experiment was an Entisol, according to Embrapa (1999). Prior to the analyses, the soil was air dried, sieved through a $4 \mathrm{~mm}$ sieve to remove gravel and coarse organic fractions (such as roots and leaves) and homogenized. The initial soil chemical characteristics were: $\mathrm{pH}\left(\mathrm{CaCl}_{2}\right)=4.2 ; \mathrm{OM}$ [organic matter] (dichromate/titration) $=13 \mathrm{~g} \mathrm{~kg}^{-1} ; \mathrm{P}($ resin $)=6 \mathrm{mg} \mathrm{kg}^{-1} ; \mathrm{K}$ (resin), $\mathrm{Ca}($ resin $), \mathrm{Mg}$ (resin), $\mathrm{Al}(\mathrm{KCl}), \mathrm{H}+\mathrm{Al}$ (SMP buffer), $\mathrm{SB}$ [sum of bases] and $\mathrm{CEC}$ [cation exchange capacity] $=0.8,2.0,1.0,4.0,18.0,3.8$ and $21.8 \mathrm{mmol}_{\mathrm{c}} \mathrm{kg}^{-1}$, respectively; and $\mathrm{V}$ [percentage base saturation] and $\mathrm{m}$ [percentage aluminum saturation] $=17$ and $51 \%$, respectively (Raij et al. 2001). Soil liming was performed 


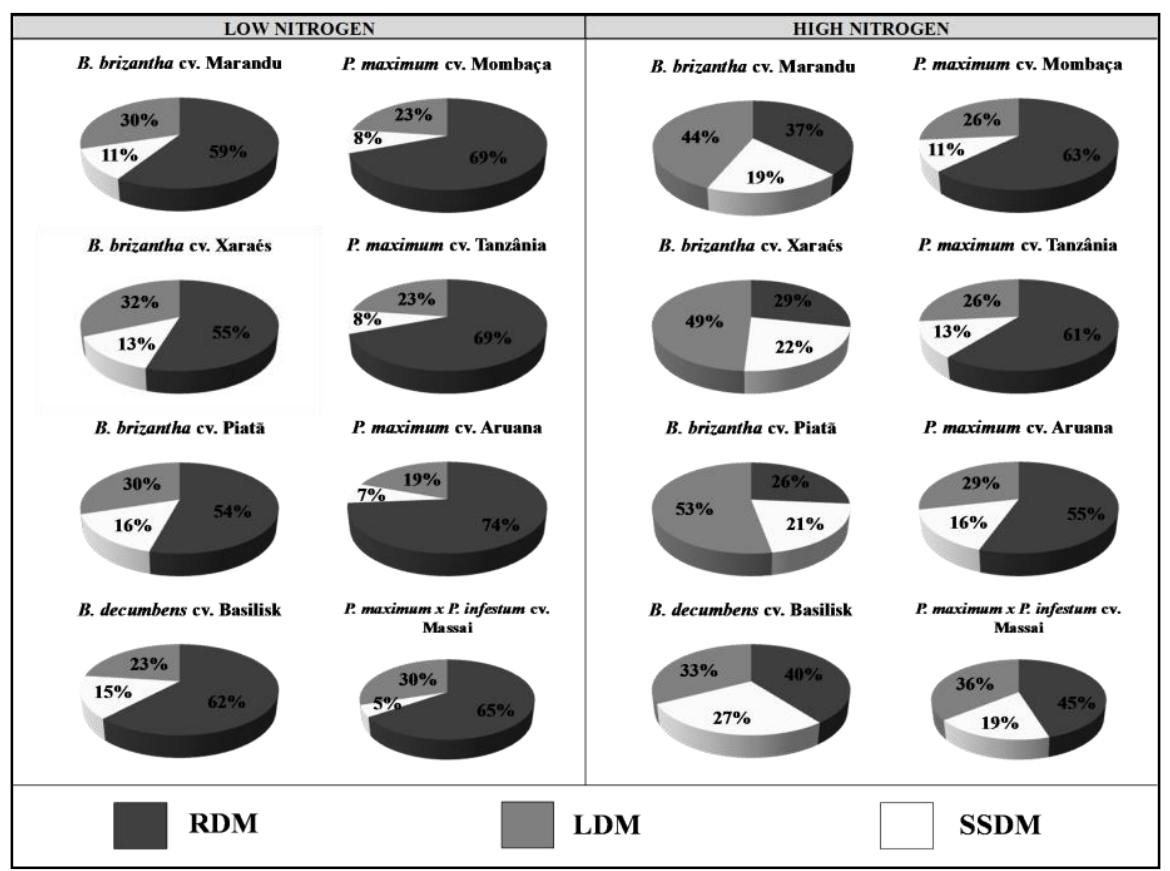

Fig 4. Proportion of the total dry matter of roots (RDM), leaves (LDM), stems + sheaths (SSDM) of Brachiaria spp. and Panicum spp. cultivars at the third harvest under low and high nitrogen rates.

by using $\mathrm{V}_{2}$ as $50 \%$ in the formula used to calculate the liming rate and by adding $\mathrm{CaO}$ and $\mathrm{MgO}$ (analytical reagents). After the acidity correction, the soil was moistened with deionized water to reach $70 \%$ water holding capacity and incubated for a period of 25 days to allow liming reaction.

\section{Irrigation system}

Water was provided by using a self-irrigating subsurface system (Bonfim-Silva et al., 2007). Water replenishment occurred continuously, maintaining the soil at $70 \%$ water holding capacity. The water replenishment system was composed of a porous ceramic capsule that was $5 \mathrm{~cm}$ in diameter and $7 \mathrm{~cm}$ in height inserted into the soil surface in the pot upper portion. This capsule was connected to a 1.5$\mathrm{cm}$ diameter flexible tube and an 1.8-L capacity reservoir positioned below the pot. Soil water potential was determined by water column height $(30 \mathrm{~cm})$ between the pot and the reservoir. Thus, soil-plant system evapotranspiration triggered the water automatic replenishment.

\section{Measurement of variables}

New leaves and tillers were determined during the three growth periods for each experimental unit. All leaves and tillers were counted at each harvest. The plant shoots were harvested at the end of each growth period and sorted into leaves and stems + sheaths. After the third harvest, roots were also collected and sorted. Total LA was determined with a LI $3100 \mathrm{C}$ leaf area meter (LI-COR ${ }^{\circledR}$, Nebraska USA). Shoots were dried at $70{ }^{\circ} \mathrm{C}$, and total dry matter of the shoots was determined by leaves and stems + sheaths summing weight.

After the third harvest, approximately $20 \%$ of root total volume was separated to determine root length (RL) and root surface area (RSA) (Rossielo et al., 1995). The root samples were stored in deionized water in plastic containers and stained with $50 \mathrm{mg} \mathrm{L}^{-1}$ solution of gentian violet for 24 hours. The roots were then spread on acetate sheets avoiding material overlap. Roots images were scanned with a HP ${ }^{\circledR}$ Scanjet 3670 scanner $(300$ dpi, Hewlett-Packard Development Company, Texas - USA). The scanned images were analyzed using SIARCS (Integrated System for Root and Soil Cover Analysis) version 3.0 software to determine RL and RSA (Crestana et al., 1994). All root samples (scanned and non-scanned) were dried at $70{ }^{\circ} \mathrm{C}$ to obtain total dry matter. Total RL and total RSA were calculated for each experimental unit based on the dry matter value for the scanned subsample.

\section{Statistical analysis}

Statistical analysis was performed using Statistical Analysis System (SAS, 2004) software. An analysis of variance was performed using the ANOVA procedure. Based on the significance of the F-tests, Tukey's tests were applied for mean comparisons at $\mathrm{P} \leq 0.05$ significance level.

\section{Conclusion}

The eight studied forage grasses differed in growth characteristics of shoots and roots under high and low $\mathrm{N}$ rates. The cultivars Mombaça and Tanzania that mostly demanded $\mathrm{N}$ prioritized both shoots and roots growths, at the two $\mathrm{N}$ rates. By contrast, Brachiaria cultivars exhibited higher plasticity of reserve allocation: at low $\mathrm{N}$ rate they prioritized roots growth but at high $\mathrm{N}$ they enhanced leaf and tiller growth. This demonstrates that Brachiaria cultivars may better withstand under stress environments, ensuring their longevity in pastures. The Panicum cultivars, especially Mombaça and Tanzania, displayed vigorous root growth suggesting more efficient capture of soil $\mathrm{N}$, which may reduce $\mathrm{N}$ losses by leaching and volatilization.

\section{Acknowledgments}

The authors thank the State of São Paulo Research Foundation (FAPESP), the Brazilian National Council for Scientific and Technological Development (CNPq) and 
Coordination of Improvement of Higher Education Personnel (CAPES) for financial support and scholarships.

\section{References}

Acuña CA, Sinclair TR, Mackowiak CL, Blount AR, Quesenberry KH, Hanna WW (2010) Potential root depth development and nitrogen uptake by tetraploid bahiagrass hybrids. Plant Soil. 334:491-499.

Akmal M, Janssens MJJ (2004) Productivity and light use efficiency of perennial ryegrass with contrasting water and nitrogen supplies. Field Crop Res. 88:143-155.

Anwar M, Akmal M, Shah A, Asim M, Gohar R (2012) Growth and yield comparison of perennial grasses as rain fed fodder production. Pakistan J Bot. 44:547-552.

Batista K, Monteiro FA (2008) Nitrogen and sulphur on morphogenic characteristics of marandu palisadegrass replacing signalgrass under degradation in a low organic matter soil. Braz J Anim Sci. 37:1151-1160.

Boddey RM, Macedo R, Tarré RM, Ferreira E, Oliveira OC, Rezende CP, Cantarutti RB, Pereira JM, Alves BJR, Urquiaga S (2004) Nutrient cycling of Brachiaria pastures: the key to understanding the process of pasture decline. Agr Ecosyst Environ. 103:389-403.

Bonfim-Silva EM, Monteiro FA, Silva TJA (2007) Nitrogen and sulfur on yield and water-use efficiency of degrading signalgrass. Rev Bras Ciênc Solo. 31:309-317.

Brégarda A, Bélanger G, Michauda R (2000) Nitrogen use efficiency and morphological characteristics of timothy populations selected for low and high forage nitrogen concentrations. Crop Sci. 40:422-429.

Burton GW (1943) A comparison of the first year's root production of seven southern grasses established from seed. $\mathbf{J}$ Ame Soc Agro. 35:192-196.

Chapman DF, Lemaire G (1993) Morphogenetic and structural determinants of plant regrowth after defoliation. In: Proceedings XIV International Grassland Congress, Palmerston North, 1993.

Crestana S, Guimarães MF, Jorge LAC, Ralish R, Tozzi CL, Torre A, Vaz CMP (1994) Evaluation of root distribution in the soil aided by digital image processing. Rev Bras Ciênc Solo. 18:365-371.

De Bona FD, Monteiro FA (2010) Marandu palisadegrass growth under nitrogen and sulphur for replacing Signal grass in degraded tropical pasture. Sci Agr. 67:570-578.

Embrapa (1999) Brazilian system of soil classification. In: Santos HG (ed.) Embrapa Solos, Rio de Janeiro, 1999.

Giacomini AA, Da Silva SC, Lucena DO, Zeferino SCV, Trindade JK, Souza Júnior SJ, GuardaVDA, Sbrissia AF, Nascimento Júnior D (2009) Growth of marandu palisadegrass subjected to strategies of intermittent stocking. Sci Agr. 66:721-732.

IBGE (2010) Sustainable development indicators. In: Forte LPS (ed.) Brazilian Institute of Geography and Statistics, Brasília, 2012.

Lemaire G, Chapman DF (1996) Tissue flows in grazed plant communities. In: Hodgson J, Illius AW (ed.) The ecology and management of grazing systems, Oxon, 1996

Liao M, Filley IRP, Palta JA (2004) Early vigorous growth is a major factor influencing nitrogen uptake in wheat. Funct Plant Bio. 31:121-129.

Martuscello JA, Faria DJG, Cunha DNFV, Fonseca DM (2009) Nitrogen fertilization and dry matter partition in xaraes grass and massai grass. Ciênc Agrotecnologia. 33:663-667.

Matthew C, Lemaire G, Hamilton NRS, Hernández-Garay AH (1995) A modified self-thinning equation to describe size/density relationships for defoliated swards. Ann BotLondon. 76:579-587.

Mommer L, Visser EJW, van Ruijven J, De Caluwe H, Pierik R, De Kroon H (2011) Contrasting root behaviour in two grass species: A test of functionality in dynamic heterogeneous conditions. Plant Soil. 344:347-360.
Nabinger C, Medeiros RB (1992) Produção de sementes de Panicum maximum. In: Peixoto AM, Moura JC, Faria VP (ed.) Manejo do capim elefante, Piracicaba, 1992.

Nabinger C, Pontes LS (2001) Morfogênese de plantas forrageiras e estrutura do pasto. In: Reunião da Sociedade Brasileira de Zootecnia, Piracicaba, 2001.

Noulas C, Liedgens M, Stamp P, Alexiou I, Herrera JM (2010) Subsoil root growth of field grown spring wheat genotypes (Triticum aestivum $L$.) differing in nitrogen use efficiency parameters. J Plant Nutr. 33:1887-1903.

Oliveira AB, Pires AJV, Matos Neto U, Carvalho GGP, Veloso CM, Silva FF (2007) Morphogenesis of Tanzania grass submitted to fertilization and harvest intensities. Braz J Anim Sci. 36:1006-1013.

Parsons AJ, Leafe EL, Collet B, Penning PD, Lewis J (1983) The physiology of grass production under grazing. I. Characteristics of leaf and canopy photosynthesis of continuously-grazed swards. The J Apply Ecol. 20:117-126.

Pilbeam DJ (2011) The utilization of nitrogen by plants: a whole plant perspective. Ann Plant Rev. 42:305-351.

Raij B van, Andrade JC, Cantarella H, Quaggio JA (2001) Análise química para avaliação da fertilidade dos solos tropicais. In: Raij vB (ed.) Instituto Agronômico de Campinas, Campinas, 2001.

Rao IM, Ayarza MA, Garcia R (1995) Adaptive attributes of tropical forage species to acid soils I. Differences in plant growth, nutrient acquisition and nutrient utilization among $\mathrm{C}_{4}$ grasses and $\mathrm{C}_{3}$ legumes. J Plant Nutr. 18:2135-2155.

Rossielo ROP, Araújo AP, Manzatto CV, Fernandes MS (1995) Comparison of the photoelectric and the intersection methods of estimating root area, root length and mean root radius. Pesq Agrop Bras. 30:633-638.

Ryser P, Lambers H (1995) Root and leaf attributes accounting for the performance of fast-and slow-growing grasses at different nutrient supply. Plant Soil. 170:251-265.

Santos MER, Fonseca DM, Balbino EM, Monnerat JPIS, Silva SP (2009) Tiller characteristics in nitrogen-fertilized and deferred signalgrass pastures. Braz J Anim Sci. 38:643-649.

Santos MER, Fonseca DM, Pimentel RM, Silva GP, Gomes VM, Silva SP (2011) Number and weight of tillers in signalgrass pasture under continuous stocking. Acta Sci. 33:131-136.

Santos PM, Thornton B, Corsi M (2002) Nitrogen dynamics in the intact grasses Poa trivialis and Panicum maximum receiving contrasting supplies of nitrogen. J Exp Bot. 53:21672176.

Santos PM, Thornton B, Corsi M (2012) Adaptation of the C4 grass Panicum maximum to defoliation is related to plasticity of $\mathrm{N}$ uptake, mobilisation and allocation patterns. Sci Agr. 69:293-299.

SAS (2004) SAS® 9.1.2 windows. In: SAS Institute, Cary, 2004. Vendramini JMB, Sollenberger LE, Lamb GC, Silveira ML (2013) Herbage accumulation, nutritive value and persistence of Mulato II in Florida. Trop Grasslands. 1:123-124.

Vilela HH, Sousa BML, Santos MER, Santos AL, Assis CZ, Rocha GO, Faria BD, Nascimento Júnior D (2012) Forage mass and structure of piatã grass deferred at different heights and variable periods. Braz J Anim Sci 41:1625-1631.

Yaseen M, Malhi S (2009) Differential growth response of wheat genotypes to ammonium phosphate and rock phosphate phosphorus sources. J Plant Nutr 32:410-432. 